\title{
Decoding the DNA of Employee Job Satisfaction
}

\author{
Saira Zahoor \\ Department of Management Sciences, The Islamia University of Bahawalpur, Pakistan \\ Sa.zahoor2@gmail.com \\ Sidra Rafiq \\ Department of Management Sciences, The Islamia University of Bahawalpur, Pakistan \\ Sid_cute15@yahoo.com
}

\begin{abstract}
Anam Zia
Department of Management Sciences, The Islamia University of Bahawalpur, Pakistan Anam_zia@hotmail.com
\end{abstract}

Muhammad Rizwan

Lecturer, Department of Management Sciences

The Islamia University of Bahawalpur, Pakistan

E-mail: rizwan.arshad@iub.edu.pk

Doi:10.5296/ ijhrs.v4i2.5903 URL: http://dx.doi.org/10.5296/ ijhrs.v4i2.5903

\begin{abstract}
The main purpose of this study is to tell, what employee satisfaction is? Employee satisfaction as a pleasurable or positive emotional state resulting from the appraisal of one's job or job experience." A sample of 150 respondents was selected to participate in self-Administered questionnaires from various public and private organizations the survey was conducted in 2013. Convenient sampling was used to collect data. Statistically association of locus of control, pay and promotion with employee satisfaction showed significant result but the relationship of training and development employee empowerment, procedural justice with employee satisfaction is insignificant; furthermore the effect of employee satisfaction on turnover intention, job loyalty and job performance is also significant. We identify that turnover intention contributes more rather than the other variables and it has a significant negative relationship with employee satisfaction. This study helps the organization for understanding about employee satisfaction how to increase
\end{abstract}


the level of employee satisfaction in public or private both sectors.

Keywords: Job Satisfaction, Locus of Control, Employee Empowerment, Procedure Fairness

\section{Introduction}

Now-a-days organizations are frequently challenging new working trends and communication, rapid change of technology, new rules and environmental and social aspects. These fundamentals aspects may have an effect on environmental work which reflects to employee's attitudes and actions with respect of their input. Researchers and field experts mostly focused the factors that have an effect on the employee satisfaction at their work environment. Work plays a major function in our lives. It occupies more time than any other single activity and provides the economic fundamental elements for our way of life Therefore, employee satisfaction is a key research area for many researchers and it is the most important frequently studied work behavior. Employee satisfaction is a thought or has an effective response which gives detail of every aspect of the situation. Research has been conducted on the topic of employee satisfaction in the past 65 years (e.g. Hop pock, 1935). The most important reason for the continuing interest in employee satisfaction, as Wilson and Resenfeld (1990) stated that positive and negative attitudes towards any work may have powerful effect on numerous forms of organizational behavior. Concerning to the latter, research findings have described that numerous personal characteristics which have an effect on employee satisfaction in different and difficult ways. Among these personal traits is gender, and parental status, age; working experience, marital etc.

In literature, large amount of predictors like salary, opportunities for higher promotion, personal safety, contact and transformational leadership, nature of work, career improvement and management have been examined through the perspective of health communication and educational institutions of Pakistan. Employee satisfaction is linked to how people think, feel and perceived their jobs. Employees may be strike with different elements for employee satisfaction .that's why it needs to inspect different factors that can maintain satisfaction of employee. Employee satisfaction has been used as a behavioral facet of employees towards the organization. Employee satisfaction is real point to which people want or avoid in their jobs.

Following the management models and method which developed by the private firms, public organization has shown a great interest in researching the satisfaction of their employees. employee satisfaction is a key variable that is able to give an opinion about general emotion and thinking forms of employees about their job and working condition, employee satisfaction is a function of the level to which one's needs are satisfied in a job (Togia et al, 2004)

Human resource is most essential beneficial part for the development of an organization. It is the source that able to makes other source use and gets best outcome of them. But getting best human resource needs vast moves by organization and their administration If the employee or human resource are pleased and satisfied with their work in organization in this way they do 
their best for the best of Organization. Management always uses the technique for the satisfaction of their employees. If the level of satisfaction is the greater the outcome will be returns for organization is the higher and this has been realized by different researchers, scholars, writer, leader, and academicians, Employee satisfaction is considered the most widely researched area for researcher (keung -fai, 1996 George and jones 2008).

The various techniques for the satisfaction of the employees were establish by the scholars and facilitated to the HR managers to attract, inspire and retained the most loyal employees. Employee satisfaction is not the similar as motivation; even though it is clearly associated .job design aims to improve employee satisfaction and performance techniques including job rotation, job enlargement and in job improvement .The contentment of the workers is an sign of the employee's satisfaction as it is a measure of sincerity and commitment of the employees with their jobs and working environment. According to Lai Wan (2007) employee satisfaction is an key objective for organization to attain, as it has been shown that productivity, output, employee maintenance and satisfaction of customer are linked to employee satisfaction. Contentment, supports employees create higher level of customer satisfaction and in return have an positive effect on the organizational performance.

Factors that led to employee satisfaction are called motivators and consist of attainment appreciation work itself, liability and progress. Luthans (1992) has mentioned five dimensions comprising pay, traits of job, work place, administration, politics and co workers. According to Drummond and stoddard (1991), employees satisfaction contains an

Analysis of different traits of the job Total quality management state that employee contribution and response improves employee satisfaction, employees feel they are the key element of organization and are support to more participation for the improvement of the system.

Empowerment as giving out knowledge, information and power with subordinates According to Conger and kanungo empowerment as a motivational conception associated to personal efficiency and define empowerment as improving the feeling of self efficiency of employees. When the nature of empowerment observed that empowerment does not yield beneficial outcomes .when psychological and behavioral empowerment are treated as a whole their relationship with jobs satisfaction then it will be handled in a more efficient and effective way that it is thought to be more comprehensive. The objective of our study is to know about the factors that affect the satisfaction level of employees in an organization how much they effect specifically, we took employee empowerment, pay \& promotion, LOC (locus of control), fairness of procedures, and training and development as the independent variables to see their effect on employee satisfaction level of employees and further their effect on job performance, turnover intention and job loyalty.

This study uses the new model of employee satisfaction to assess the impact of fairness of procedures, pay \& promotion, LOC (locus of control), employee empowerment and training and development on employee satisfaction and further study their effect on job performance, job loyalty and turnover intention. The concept of fairness was used as equality in procedures and perception of the way in which decisions are taken in any organization .pay and 
promotion are very important factors in the employee satisfaction. As one aspect of personality, LOC measures personal characteristics for either the need for internal or external control of strengthening.

Employee empowerment gives employees the independence for decisions power about their daily activities (careless, 2004; haas, 2010). In an organization terms training is used as a set of designed activities to increase the employee information and abilities about the job in a way consistent with the object of organization. If the level of satisfaction will be higher then the job performance level also higher. According to the definition of mathieu and zajac (1990), loyalty means as connection to the organization that may be considered an emotional reaction when an employee believes strongly in organizational objective and norms and has a strong wish to keep membership of the organization. In a broader definition of the construct, it can be understood as the intention to willingly change companies or to leave the labor market altogether. We included turnover intention rather than actual turnover in our study for numerous reasons. First, we were interested in the present employees rather than those who had already left the organization. Second, actual turnover is effect by the economic environment and by conditions on the labor market (Carsten and Spector, 1987; Dipboye et al., 1994). This means that the actual turnover would not give us a correct insight into the effects of employee satisfaction

\section{Literature review:}

\subsection{Employee satisfaction}

According to spector, Employee satisfaction has been related with how people think, feel and perceive their jobs (Spector, 1997).Employee satisfaction is considered within experimental studies either as an overall feeling about the job, or as a related set of attitudes about several aspects of the job (Spector, 1997). Locke (1976) employee satisfaction defined as "[. . .] a pleasant or positive emotional condition resulting from the assessment of job experience." Employee satisfaction is an essential variable that give an opinion about general feeling and different views of employees about their job and working condition. Thus, employee satisfaction refers to hope of the employee about the working conditions and his behavior to forward his job. As a result, employee satisfaction is a function of the degree to which one's needs are content in a job (Togia et al., 2004).

According to many researchers, employee satisfaction has been used as a behavioral characteristic of employee toward the organization (Cranny et al., 1992; Sweeney et al., 2002). there are many theories regarding the fundamental relationship between behavior proceeds and motives,. For example, employee satisfaction can be seen as a result of a behavioral cycle; it can be seen on a basis of behavior; or it can be seen as a piece of an instruction system in which the assessment of results leads to decisions regarding whether or not changes are to be made (Thierry, 1997). These fundamental theories effect the definitions of employee satisfaction.

Some definitions involve a differentiated approach in which employee satisfaction is seen as consisting of satisfaction with different feature of the job and the work situation. In this 
approach, employee satisfaction is assessed by adding the satisfaction reported for many different characteristics of the job and the work situation. This type of evaluation gives an exact picture of the employees' total employee satisfaction.

\subsection{LOC (locus of control)}

As one aspect of personality, LOC measures an individual's traits for external and internal control. (Rotte, 1966). Specifically, it refers "to the level to which people believe their own capacities or external factors, such as chance situation and power of others, are in control of the events that control their lives" (see Firth et al., 2004). Individuals with a low LOC score have an internal LOC (internals) and generally believe that their own behavior, capability or trait determine the rewards that they achieve. Individuals high LOC score which have an external LOC (externals) and they believe that they receive rewards in life they generally give credit to the outside factors.(Rotter, 1966).

A locus of control is a person's belief about how much power one has over the events in one's life. According to psychologist Julian Rotter, who gave the concept about the locus of control in 1950's that is a dimension of personality; it helps to explain one's traits like character and attitude. An internal locus of control is the belief that the course of one's life is largely up to oneself. Those with an internal locus of control regard the events in their lives as happening due to their own efforts. People who have an internal locus of control tend to be less affected by others, more politically active, and more motivated to achieve. Numerous researchers believe an internal locus of control is more beneficial than an external one. So the people who have internal LOC are more satisfied with their Job as compare to the people who have external LOC.

\section{H1: There is a relationship of LOC with employee satisfaction}

\subsection{Fairness of procedures}

Perceived procedural justice (PPJ) or fair procedures is related to those techniques by which outcome decisions are made on fairly basis (Greenberg, 1990). Constantine et al. (2008) state that procedural justice refers to fairness in procedures and awareness of the method in which decisions are taken in any organization. Lambert et al. (2007) gave the concept that fairness as an essential element of society and in organizational setting. This concept helps to know that the administration take fair decisions to distribute outcomes. The mechanism or method through which to reach an outcome is as important itself as outcome in terms of its impact on employees job attitude (Greenberg, 1987). This factor has widely been applied to know the employee satisfaction. (Lambert et al., 2007; Leventhal et al., 1980; Lambert, 2003)

The study of Lambert (2003) assessed at the impact of procedural justice on employee satisfaction and found that it has significant positive impact on employee satisfaction level. Dailey and Kirk (1992) in their study to emphasize the need of procedural justice to maintain and keep 


\section{Macrothink}

International Journal of Human Resource Studies ISSN 2162-3058 2014, Vol. 4, No. 2

Employees satisfied. Furthermore, authors state that absence of procedural justice may lead to discontent and quitting trend in employees. In the same way several studies of employee job attitudes have identified the effect of perceived fairness in processes of justice on employee satisfaction, for example, Folger and Konovsky (1989) analyze the impact of PPJ on employee satisfaction from the first line employees of private organization in USA. Further Huo et al. (1996) and McFarlin and

Sweeney (1992) studied PPJ and employee satisfaction in the context of public sector organizations and banking sector, in order that Organizations with professional employees who have high mobility must have to take into account the procedural justice perception of its employees in order to make them satisfied and effective. Lambert et al. (2007) argue that employees PPJ as fairness of process through which distributive outcomes like promotions in organization, evaluations, and rewards are decided.

\section{H2: There is a relationship of fairness of procedures with employee satisfaction}

\subsection{Pay and promotion}

Employee satisfaction is an outcome of different factors like pay, promotion, the work itself, management relationships with colleagues and opportunities for promotions (Opkara, 2002). Out of these factors, pay is a very important factor. Frye (2004) found that there is positive relationship between equity based reward and performance. Due to these factors employees motivate and give better performance.

According to the American Association Pay or Compensation is defined as "Cash and non-cash wage provided by the employer for services rendered."

It was further concluded that reward plays an important role in human capital intensive firms to capture and keep expert workers. Furthermore, the compensation has significant impact on the level of employee satisfaction of employees. It was also found that flexible compensation has no effect on the level of employee satisfaction (Igalens and Roussel, 1999). The study related to the employee satisfaction level of public sector mangers was conducted and it was resulted that the income is the important determinants of employee satisfaction (Sokoya, 2000). The investigation about relationship among employee satisfaction and pay was conducted and it was also concluded that employee satisfaction is affected by the pay (Nguyen et al., 2003)

\section{H3: There is a relationship of pay and promotion with employee employee satisfaction}

\section{5 .Employee empowerment}

It related to a form of employee contribution program (Wilkinson, 1998) and refers to the 
level with which employees are motivate to make definite decisions without consulting their management, so that organizational dynamics are started at the bottom (Michailova, 2002). Empowerment practices decentralize power by involving employees in decision making (Carless, 2004). This feature of empowerment is related with the behavior of a supervisor (Lee and Koh, 2001) and so empowerment can be defined as a discretionary construct that has management providing employees with good judgment and independence over their tasks (Hsieh and Chao, 2004). It focuses on the relationships between team leaders and subordinate (Lee and Koh,

2001) and on the employee's awareness of their individual power to manage with the events, situations and people they encounter at work (Carless, 2004). Empowerment implies that people at the lower levels of organizations to take better decisions and important decisions can be made at all levels of organizations (Robert et al., 2000). It motivates service employees to use their own judgment to make quick decisions (Lovelock, 1992; Humborstad et al., 2008b). In brief, empowerment practices could motivate individual frontline service employees to convey high-quality service as a discretionary effort (Malhotra and Mukherjee, 1999; Hancer and George, 2003). Empowerment involves creating values for employees to do their job independently without stable involvement of management (Ampofo-Boateng et al., 1997). Velthouse (1990) defined empowerment as one's belief in his/her ability to employ choice. Aim of the employee empowerment is to develop individual and organizational performance and to help employees achieve their goals by authorizing employees to participate in the decision-making process. Employees think about their own jobs, and find and solve problems related to their job (Seibert et al., 2004; Jun et al., 2006). From an employee's viewpoint, feelings of empowerment should have a positive impact on attitudinal responses and satisfaction from job (Snipes et al., 2005).So there is

\section{H4: There is a relationship of employee empowerment with employee satisfaction}

\subsection{Training and development}

Training and development is a set of designed activities on the element of a business to increase the information and abilities about job in a way consistent with the objectives of an organization (Landy, 1985). Employee training provides opportunities to employees broaden their information and skills for more effective and efficient teamwork and attain individual development (Jun et al., 2006). When workforce receives self-development training, their satisfaction level is higher than untrained employee (Saks, 1996).

Martensen and Gronholdt (2001) notice that the development has a positive effect on employees competencies through different training programs. Employees gain self-confidence of making their jobs when they attend different development programme, they perceive that their companies make investment in them and they think they have career development opportunities in this organization (Jun et al., 2006). As result of this positive situations, employee satisfaction increases. Several authors argue that training is an essential 
predictor the positive attitudes of employee (Shields and Wheatley, 2002; Schmidt, 2007a, b). Georgellis and Lange (2007) describe job training is accessibility of written materials for learning, courses, participation in conferences and conduct saminars for the employees in organization.

\section{H5: There is a relationship of training and development with employee job Satisfaction}

\subsection{Job Performance}

Job performance measures the level of attainment of business and social goals responsibilities and duties from the point of view of judging part (Hersey and Blanchard, 1993). According to Porter and Lawler (1968), there are three types of performance. One is the measure of outcome rates, sales in a given period of time, the production of a group of employees reporting to manager, and so on. The secondly measure of performance through ratings of individuals comparing with other person whose performance is being measured the third type of performance measures is self-appraisal and self-ratings. As a result, the adoption of self-appraisal and self-rating methods are helpful in encouraging employees to take an active role in setting his or her own objectives. Brudney and Coundry (1993) have explained different variables that influence performance of the employees in the organization

\section{H6: There is a relationship of $\mathrm{LOC}$ with job performance}

H7: There is a relationship of job performance with employee job satisfaction

\subsection{Turnover intention}

Next, we turn to the relationship between employee satisfaction and turnover intention, Turnover intention is defined as the intention to leave a job willingly (Mobley, 1977). In a broader definition of the construct, it can be understood as the intention to willingly change organizations or to leave the labor market altogether. We included turnover intention rather than real turnover in our study for a number of reasons. First, we were interested in the present employees rather than those who had already left the organization. Second, actual turnover is influenced by the economic atmosphere and by conditions on the labour market (Carsten and Spector, 1987; Dipboye et al., 1994). If we concern real turnover we cannot found accurate effects of employee satisfaction on turnover intention as a result, we chose to employ turnover intention, keeping in mind that research results suggest that turnover intention does finally lead to real turnover (Mobley et al., 1978; Steel and Ovalle, 1984). at first, we will now outline the direct effects of employee satisfaction on turnover intention .in the past researches This statement is confirmed, the negative relationship between turnover intention and employee satisfaction (e.g. Mathieu and Zajac, 1990; Mobley et al., 1978; Williams and Hazer, 1986). 
H8: There is a relationship of employee satisfaction with turnover intention

\subsection{Job loyalty}

Here we will find the relationship between Employee satisfaction and Job Loyalty,

According to Allen and Grisaffe (2001), loyalty is a psychological state and it characterizes the relationship of an employee with the organization for which they work and that has implications

for their decision to stay with the organization. According to the Mathieu and Zajac (1990), loyalty means as affection $0 \mathrm{n}$ the organization that may be considered an emotional reaction, especially when an employee believes strappingly in organizational objective, norm and values and has a wish to sustain membership with their organization. According to Becker et al. (1995), loyalty could be defined as a strong desire to continue a associated of his organization; a readiness to strike on high levels of efforts for the sake of the organization; and a definite belief in and acceptability of the values and goals of the organization Thus, loyalty is characterized by the strong wish to maintain membership of an organization, which plays a positive role in maintenance of members in the organization.

Organizational loyalty of employees could be defined as "the relative strength of an individual's identification with and involvement in a particular organization" (Wu and Norman, 2006). While employee satisfaction represents an effective response to specific features of the job and an attitude toward a job, employee loyalty is an effective response to the whole organization (Chen, 2006). Experimental evidence suggests that employee satisfaction is an antecedent to organizational loyalty of employees. This means that organizational loyalty of employees develops from employee satisfaction, such that loyalty mediates the effects of satisfaction on turnover variables (Chen, 2006). Employee satisfaction has a positive impact on organizational loyalty of employees (Fletcher

and Williams, 1996). According to Martensen and Gronholdt (2001), employee satisfaction is positively connected to employees' loyalty to their organization. Also, some studies such as Al-Aameri (2000) and Fang (2001) also constantly report a strong relationship between organizational loyalty of employees and employee satisfaction (Wu and Norman, 2006).

\section{H9: There is a relationship of employee satisfaction with job loyalty}




\section{Macrothink

\section{Research model}

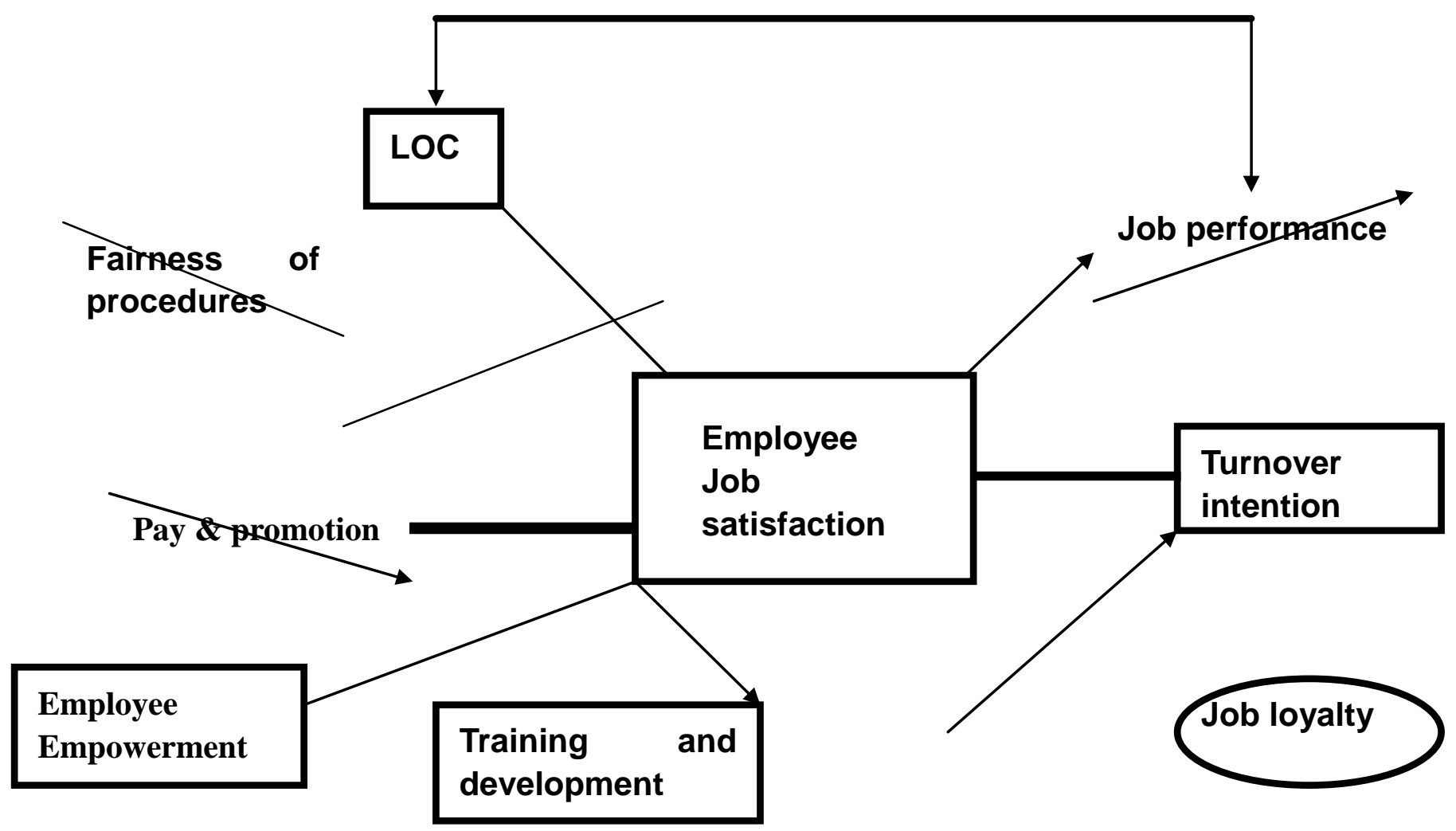

\section{Research Methodology:}

The current research is descriptive in its nature. Descriptive research can be explained as describing something, some phenomenon or any particular situation. Descriptive researches are those researches that describe the existing situation instead of interpreting and making judgments (Creswell, 1994). The main objective of descriptive research is verification of the development hypotheses that reflect the current situation. This type of research provides information about the current scenario and focus on past or present for example quality of life in a community or customer attitudes towards any marketing activity (Kumar,2005).

\subsection{Sample/Data:}

In order to collect the data for understanding the employee satisfaction level in various organizations. A Sample of 180 respondents will ask to participate in a self Administered questionnaires. The population for the current research is the employee from Public sector or Private sector organization in Bahawalpur.

It has ensured that the sample members posses different qualification \& scale of Job to participate in the self administrated survey. The main clustered were targeted to collect the sample data of university employee and banks. 


\section{Macrothink}

\subsection{Instrument \& scale:}

The survey Instrument of the current study addresses two major purpose first is analysis the relationship of different variables with employee satisfaction. Second to collect the information about the different characteristics of the respondents that can be used to understand the variation of different categories.

The survey Instrument contains two sections. Section one include different personal \& demographic variables this section will obtain the respondents information about gender, age, Income, education. Section two include the latent variable that are important in the current study these variable include Employee satisfaction, Pay\& promotion, Locus of control , Employee Empowerment, Training \& Development, Job Loyalty and Turnover Intention. This section on the base of past study $\&$ already used questionnaire.

Table 1: Scales of the Study

\begin{tabular}{|c|c|c|c|}
\hline No. & Variable & Items & Reference \\
\hline 1 & $\begin{array}{l}\text { Employee } \\
\text { Satisfaction }\end{array}$ & $\begin{array}{l}\text { 1.I find my work very satisfying } \\
\text { 2.I feel that I am really doing } \\
\text { something worthwhile in my job } \\
\text { 3.My work is challenging } \\
\text { 4.My job is very interesting } \\
\text { 5.My work gives me a sense of } \\
\text { accomplishment }\end{array}$ & $\begin{array}{l}\text { Churchill et al. } \\
\text { (1974). }\end{array}$ \\
\hline 2 & Locus of Control & $\begin{array}{l}\text { 1.I can anticipate difficulties and take } \\
\text { action to avoid them } \\
\text { 2. When I make plans, I am almost } \\
\text { certain that I can make them work } \\
\text { 3.My mistakes and problems are my } \\
\text { responsibility to deal with } \\
\text { 4.Becoming a success is a matter of } \\
\text { hard work luck has little or nothing to } \\
\text { do with it } \\
\text { 5.I believe a person can really be a } \\
\text { master of his fate } \\
\text { 6.I am confident of being able to deal }\end{array}$ & Roger, 1966 \\
\hline
\end{tabular}




\begin{tabular}{|c|c|c|c|}
\hline & & successfully with future problems & \\
\hline 3 & Pay and Promotion & $\begin{array}{l}\text { 1.I am satisfied with the existing } \\
\text { salary structure of the company } \\
\text { 2.I am satisfied with the compensation } \\
\text { I get \& I think it matches with my } \\
\text { responsibility } \\
\text { 3.I will be promoted within the next } \\
\text { two years }\end{array}$ & (Hayes, 1994) \\
\hline 4 & $\begin{array}{l}\text { Employee } \\
\text { Empowerment }\end{array}$ & $\begin{array}{l}\text { 1.I am encouraged to handle } \\
\text { customer/daily problems by myself } \\
\text { 2.I have control over how I solve } \\
\text { customer problems } \\
\text { 3.I have the authority to correct } \\
\text { customer problems when they occur }\end{array}$ & $\begin{array}{ll}\text { Hackman } & \text { and } \\
\text { Oldham, 1975) } & \end{array}$ \\
\hline 5 & Job Performance & $\begin{array}{l}\text { 1.My performance is better than that } \\
\text { of my colleagues with similar } \\
\text { qualifications } \\
\text { 2.I am satisfied with my performance } \\
\text { because it is mostly good } \\
\text { 3.My performance is better than that } \\
\text { of Bankers with similar qualifications } \\
\text { in other Banks }\end{array}$ & $\begin{array}{l}\text { (Bowra et al., } \\
\text { 2011) }\end{array}$ \\
\hline 6 & $\begin{array}{l}\text { Fairness } \\
\text { Procedures }\end{array}$ & $\begin{array}{l}\text { 1.Job decisions are made by the } \\
\text { manager in an unbiased manner } \\
\text { 2.My manager makes sure that all } \\
\text { employee concerns are heard before } \\
\text { job decisions are made } \\
\text { 3.To make job decisions my manager } \\
\text { clarities decisions and provides } \\
\text { additional information when } \\
\text { requested by employee } \\
\text { 4.Employees are allowed to challenge } \\
\text { or appeal job decisions made by the } \\
\text { manager }\end{array}$ & $\begin{array}{ll}\text { Hackman } & \text { and } \\
\text { Oldham, 1975) } & \end{array}$ \\
\hline
\end{tabular}




\begin{tabular}{|c|c|c|c|}
\hline 7 & Turnover Intention & $\begin{array}{l}\text { 1.I will likely actively look for a new } \\
\text { job in the next year } \\
\text { 2.I often think about quitting } \\
\text { 3.I probably look for a new job in the } \\
\text { next year }\end{array}$ & $\begin{array}{l}\text { Cummann et al. } \\
(1979)\end{array}$ \\
\hline 8 & $\begin{array}{l}\text { Training and } \\
\text { Development }\end{array}$ & $\begin{array}{l}\text { 1.My company provides me the } \\
\text { opportunity to improve skill } \\
\text { 2.There is lot of chance to learn new } \\
\text { things in the company } \\
\text { 3.My company frequently arrange } \\
\text { training programs for the employees } \\
\text { 4.Doing job in this company will } \\
\text { benefit me in the future } \\
\text { 5.I am satisfied with the training and } \\
\text { development provided by the } \\
\text { company }\end{array}$ & $\begin{array}{l}\text { Hackman and } \\
\text { Oldham, 1975) }\end{array}$ \\
\hline 9 & Job Loyalty & $\begin{array}{l}\text { 1.I want to continue my work in the } \\
\text { same organization } \\
\text { 2.I would like to advise my friends to } \\
\text { do work in this organization } \\
\text { 3.When somebody speak ill of my } \\
\text { organization, I will defend } \\
\text { immediately } \\
\text { 4.I would support my organization in } \\
\text { almost any emergency } \\
\text { 5.No matter whether it will benefit me } \\
\text { or not, I will be willing to continue } \\
\text { working under my organization's } \\
\text { policy } \\
6 . \text { When someone praise my } \\
\text { organization, I feel like a personal } \\
\text { compliment }\end{array}$ & $\begin{array}{l}\text { Hackman and } \\
\text { Oldham, 1975) }\end{array}$ \\
\hline
\end{tabular}

\subsection{Procedure:}

The Questionnaire was distributed among 180 respondents in Bahawalpur. These respondents 
are selected based on the criteria above mentioned. Before giving the questionnaire, the purpose of study and questionnaire were explained to the respondents so they can easily fill the questionnaire with relevant responses. A total of 150 questionnaires were selected and rest of the questionnaires was not included in the future analysis due to incomplete or invalid responses. After collecting the completed questionnaires, these questionnaires were coded and entered into SPSS sheet for further analysis.

\subsection{Reliability Analysis:}

All the variables of our research study were reliable as their Cronbach Alpha values were greater than acceptable and recommended value 0.50 by Nunnally (1970) and 0.60 by Moss et al. (1998). This shows that all the items were reliable and valid to measure the opinions of consumers towards Employee satisfaction.

Table 2:

\begin{tabular}{|l|l|l|}
\hline Scales & Items & Cronbach Alpha \\
\hline Locus of Control & 5 & 0.823 \\
\hline Fairness of Procedures & 4 & 0.764 \\
\hline Pay \& Promotion & 3 & 0.714 \\
\hline Employee Empowerment & 3 & 0.811 \\
\hline Training \& Development & 5 & 0.814 \\
\hline Employee satisfaction & 5 & 0.823 \\
\hline Job Performance & 3 & 0.694 \\
\hline Turnover Intention & 3 & 0.754 \\
\hline Job Loyalty & 6 & 0.825 \\
\hline
\end{tabular}

\section{Result \& Analysis:}

\section{1: Profile of the Respondents:}

Personal and Demographic information such as Gender, Age, Income, Education level, of Employee satisfaction are represented in the following table. 
Table 3:

\begin{tabular}{|c|c|c|c|}
\hline Variable & Category & Frequency & Percentage \\
\hline \multirow[t]{2}{*}{ Gender } & Male & 72 & 45 \\
\hline & Female & 78 & 48.8 \\
\hline \multirow[t]{5}{*}{ Age } & 20-25 years & 54 & 33.8 \\
\hline & 25-30 years & 53 & 33.1 \\
\hline & 30-35 years & 15 & 9.4 \\
\hline & $35-40$ years & 8 & 5.0 \\
\hline & Above 40 years & 20 & 12.5 \\
\hline \multirow[t]{6}{*}{ Income } & Below 15000 & 38 & 23.8 \\
\hline & $15000-25000$ & 26 & 16.2 \\
\hline & $25000-35000$ & 21 & 13.1 \\
\hline & $35000-45000$ & 16 & 10.0 \\
\hline & $45000-50000$ & 14 & 8.8 \\
\hline & Above 50000 & 35 & 21.9 \\
\hline \multirow[t]{6}{*}{ Education } & Matriculation & 2 & 1.2 \\
\hline & Inter & 13 & 8.1 \\
\hline & Bachelor & 32 & 20.0 \\
\hline & Master & 44 & 27.5 \\
\hline & MS/ M.Phil & 30 & 18.8 \\
\hline & PHD & 29 & 18.1 \\
\hline
\end{tabular}

\subsection{Hypothesis Testing:}

\subsubsection{Locus of control and Employee Satisfaction:}

According to the results of the study the Locus of control have a significant positive relationship with Employee Satisfaction? The Locus of control has a significant positive relationship $(\beta=0.413)$ and $(\mathrm{P}=0.000)$ that means Locus of control contribute more than $41 \%$ to employee satisfaction result of current study validate $\mathrm{H} 1$. 


\section{MlMacrothink}

\subsubsection{Locus of control and Job Performance:}

The regression result of study confirm the significant positive relationship between LOC \& Job performance with $(\beta=.213)$ and $(p=.014)$. According to these result LOC contribute more than $21 \%$ to Job performance. These results of study validate $\mathrm{H} 2$.

\subsubsection{Employee satisfaction and Job Performance:}

Regression Analysis of employee satisfaction model show that there is significant positive relationship between employee satisfaction and job performance with $(\beta=.393)$ and $(p=.000)$ the result suggest that the employee satisfaction contribute almost $39 \%$ to Job Performance. These results of study validate $\mathrm{H} 3$.

\subsubsection{Fairness of procedures and Employee Satisfaction:}

According to the result there is no significance relationship between fairness of procedure and Employee satisfaction with $(\beta=.058)$ and $(p=.527)$ based on these result we reject $\mathrm{H} 4$ and conclude that the study did not find significant relationship of fairness of procedure with employee satisfaction.

\subsubsection{Pay \& Promotion and Employee Satisfaction:}

According to the result of the study the pay \& promotion has a significant positive relationship with Employee satisfaction .Pay \& Promotion has a significant positive relationship with $(\beta=.242)$ and $(p=.004)$ that means pay \& promotion contribute more that $24 \%$ to Employee satisfaction. These results of study validate H5.

\subsubsection{Employee Empowerment and Employee satisfaction:}

According to the results there is no significant relationship between Employee Empowerment and Employee satisfaction with $(\beta=.040)$ and $(p=.647)$ based on their result we reject H6 and conclude that the study did not find significant relationship of employee empowerment with Employee satisfaction.

\subsubsection{Training \& Development and Employee satisfaction:}

According to result there is no significance relationship between training7 development and Employee satisfaction with $(\beta=.030)$ and $(p=.710)$ based on their result we reject $\mathrm{H} 7$ and conclude that the study did not find significant relationship of training 7 development with employee satisfaction.

\subsubsection{Employee satisfaction and Job Loyalty:}

The regression result of the study confirm the significant positive relationship between Employee satisfaction and Job loyalty with $(\beta=.604)$ and $(p=.000)$. According to these result Employee satisfaction contribute more than $60 \%$ to the Job loyalty .these result of study validate $\mathrm{H} 8$.

\subsubsection{Employee Satisfaction and Turnover Intention:}

The Regression result of the study confirm the significant negative relationship between 
employee satisfaction and turnover intention with $(\beta=.074)$ and $(p=.370)$. According to these result Employee satisfaction contribute more than $74 \%$ to turnover intention

Table: 4

\begin{tabular}{|c|c|c|c|c|c|c|}
\hline Hypothesis & $\begin{array}{l}\text { Model } \\
\text { Variables }\end{array}$ & Estimate & S.E. & C.R & $\mathrm{P}$ & Results \\
\hline $\mathrm{H} 1$ & LOC $^{\rightarrow}$ E.S & 0.413 & 0.000 & 5.078 & 0.000 & Supported \\
\hline $\mathrm{H} 2$ & F.P ${ }^{\rightarrow}$ E.S & 0.058 & 0.527 & 0.634 & 0.527 & $\begin{array}{l}\text { Not } \\
\text { Supported }\end{array}$ \\
\hline $\mathrm{H} 3$ & PAP $^{\rightarrow}$ E.S & 0.242 & 0.004 & 2.950 & 0.004 & Supported \\
\hline $\mathrm{H} 4$ & E.E $\mathrm{E}^{\rightarrow}$ E.S & 0.040 & 0.647 & 0.458 & 0.647 & $\begin{array}{l}\text { Not } \\
\text { Supported }\end{array}$ \\
\hline $\mathrm{H} 5$ & TAD $^{\rightarrow}$ E.S & 0.030 & 0.710 & 0.373 & 0.710 & $\begin{array}{l}\text { Not } \\
\text { Supported }\end{array}$ \\
\hline H6 & LOC $^{\rightarrow}$ J.P & 0.213 & 0.014 & 2.483 & 0.014 & Supported \\
\hline $\mathrm{H} 7$ & E.S $\rightarrow$ J.P & 0.393 & 0.000 & 4.594 & 0.000 & Supported \\
\hline H8 & E. $S \rightarrow T^{T}$.I & 0.074 & 0.370 & 0.900 & 0.370 & Supported \\
\hline H9 & E.S $\rightarrow$ J.L & 0.604 & 0.000 & 9.214 & 0.000 & Supported \\
\hline
\end{tabular}




\section{Macrothink

Figure: Structural Model Results

\section{Structural model Results}

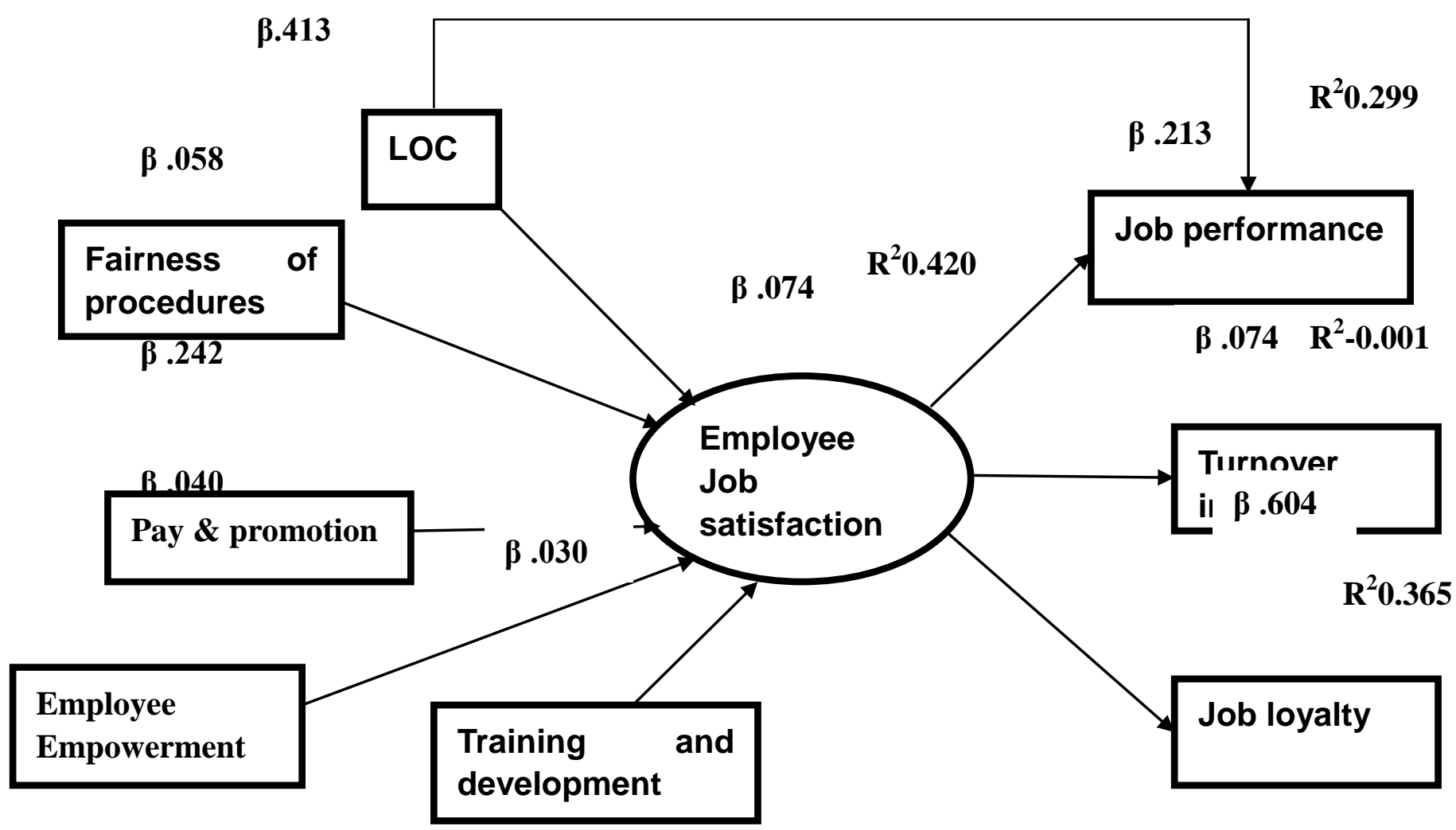

\section{Discussion:}

This study has been conducted in the both sectors of Bahawalpur City (private sector as well as in public sector organization). The main objective of this research is to get the more knowledge about the factors that have effect on employee satisfaction in any organization; it's not matter whether it is private or public sector organization. We analyze many of the past researches and choose the variables from that research papers to find their effect on the organization in Bahawalpur City.

The research also ensures that is there any correlation in employee satisfaction and job loyalty? We concluded this research by taking the sample of 180 employees from target population, 150 of the employee responded to our questionnaire. Our research consists of two parts. In the first part, we use LOC, fairness of procedures, pay \& promotion, employee empowerment and training \& development as an independent variable and employee satisfaction as a dependent variable, in the second part; we took employee satisfaction as an independent variable and job performance, job loyalty and turnover intention as dependent variables. We conducted analysis on the basis of data collected from sample. 


\section{Mll Macrothink}

International Journal of Human Resource Studies

ISSN 2162-3058

2014, Vol. 4, No. 2

The result shows the locus of control has a significant positive relationship and contributes more than $41 \%$ to ES. When employee has internal locus of control then he is more satisfied with his job rather than the person who has external LOC because the person who has external LOC than they blame the other for his all action due to this he face stress and less satisfied. The study confirms that LOC has a significant positive relationship and it contributes More than $21 \%$ to job performance. If the person has internal LOC then they blame to his self for all his good or bad actions and he try to give their best due to this he perform well.

Our next variable is fairness of procedures according to the result of the study fairness of procedures has not significant relationship with employee satisfaction. It means fairness in all procedures is not more important factor. Some employees consider this factor but many of them ignore it due to this the result of this research shows there is no significance relationship. The result of the other variable shows the pay and promotion has a significant positive relationship and it contributes more than $24 \%$ to ES. When employees give their best they want to get handsome salary and promotion for their efforts.

According to the result there is no significant relationship between employee empowerment and ES. Therefore we reject this variable; it means that besides employee empowerment there are more other influential factors on ES. Some people don't want to get power to make decision at the spot they want to do their work as a subordinate under the supervisor due to this there is no significant relationship. According to the study the results shows that training and development has no significance relationship to ES therefore we reject this variable. In many organization training and development is not necessary to satisfy its employees.

The study ensures that ES has a positive relationship and it contribute $60 \%$ to job loyalty. If the person is satisfied with his job than the level of job loyalty is rise. They want to stick with this organization and have no intention to leave. According to the result the ES has a significant negative relationship and it contribute more than $74 \%$ to turnover intention. If the person is satisfy than they have less intention to leave the job. If the satisfaction level is high than the employee satisfaction level is low but if the employee satisfaction is high than the turnover intension is low Result of the analysis shows that ES has a significant positive relationship and it contributes $39 \%$ to job performance. When person is satisfied with their job than he want to see his organization at top position due to this he perform well and motivate to achieve a goal of the organization

\section{Limitation and implications:}

This study faced several limitations due to resources and time constraints. First limitation is that it has a limited number of respondent Second limitation is we use single source of data of a cross sectional basis. Third limitation is that we had confined geographical area. So if we increased sample size and area then the result is more accurate and significant several managerial implications emerge from this study by combining the theoretical perspective that examines employee satisfaction on the basis of (Locus of control), Pay and promotion, Employee Empowerment. This study Analyzed that what factor effect employee satisfaction in and how we can increase employee satisfaction employee efficiency and effectiveness in 
organization. Similarly other variables job performance, turnover intention, job loyalty, training and development fairness to procedure also include. In this study we found LOC, pay $\&$ promotion .job performance, turnover intentions and job loyalty effect the employee satisfaction. But training and development, fairness to procedure, employee empowerment no effect on employee satisfaction as past researches show that they have also significant influence over employee satisfaction

\section{References:}

1: Ampofo- Boateng, K. \& Thomson, J.A. (1990). Child pedestrian accidents: a case for preventative medicine. Health Education Research: Theory and Practice, 5, 265-274.

2: Al. Aamer, A. S. (2000).Job satisfaction and organizational commitment for nurses. Saudi Medical Journal, 21(6):513-535.

3: Becker, Howard S. (1986). Writing for Social Scientists: How to Start and Finish Your Thesis, Book, or Article. Chicago, IL: The University of Chicago Press.

4: Becker, R. H., White, R. L., Helfand, D. J., Gregg, M. D., \& McMahon, R. G. 1996, in Radio Emission from Stars and the Sun, eds. J. M. Paredes \& R. Taylor, in press

5: Carless, D. (1998). A case study of curriculum implementation in Hong Kong. System, 26(3), 353-368.

6: Carless, D. (1999). Larg scale curriculum change in Hong Kong. In K. Chris, D. Paul \& G. Christine (Eds. ), Exploring Change in English Language Teaching (pp. 19-37). Hong Kong: Macmillan Heineman.

7: Carless, D. (2003). Factors in the implementation of task-based teaching in primary Schools . System, 31(4), 485-500.

8: Carless, D. (2004). Issues in teachers reinterpretation of a task-based innovation in primary schools. TESOL Quarterly, 38(4), 639-662.

9: Carsten, J.M. and Spector, P.E. (1987), ,„,Unemployment, job satisfaction and employee turnover: a meta-analytic test of the Muchinsky modele ${ }^{\text {eee }}$, Journal of Applied Psychology, Vol. 72, pp. 374-81.

9: Creswell, J.W., Research Design: Qualitative \& Quantitative Approaches, London: SAGE Publications, 1994.

10: Chang, E. (1999), "Career commitment as a complex moderator of organizational commitment and turnover intention", Human Relations, Vol. 52 No. 10, pp. 1257-78

11: Dailey,R.C. , \& Krirk, D.J.(1992).Distributive and procedural justice as antecedents of job dissatisfaction and intent to turnover.Human Relations 45,305-317.

12: Darrow, L.E. (1971), "Empirical test of the Herzberg two-factor theory of job satisfaction”, unpublished doctoral dissertation, East Texas State University, Commerce, TX. 
13: Folger, R. 1986. Mediation, arbitration, and the psychology of procedural justice. In R. J.

Lewicki, B. H. Sbeppard, \& M. H. Bazerman (Eds.), Research on negotiation in organizations, vol. 1: 57-80. Greenwich, GT: JAI Press.

14: Folger, R., \& Konovsky, M. A. 1989. Effects of procedural and distributive justice on reactions to pay raise decisions. Academy of Management Joumal, 32: 115-130.

15: Firth,Lucy,Mello,David.J., Moore,kathlee,A.,Loquet,Clande.(2004,Novmber 2). How can managers reduce employee intention to quit? Joural of Managerial Psycology, 19(2), 170-187.

16: Greenberg, J., \& Cropanzano, R. (Eds.) (2001). Advances in organizational justice. Stanford, CA: Stanford University Press.

17: Gerbner, G. \& Gross, L. (1976). Living with television: the violence profile. Journal of Communication, 26, 173-199.

18: Gerbner, G., Gross, L., Morgan, M. \& Signorielli, N. (2002). Growing up with television: The cultivation perspective. In J. Bryant and D. Zillmann (Eds.), Media effects: Advances in theory and research. Hillsdale, NJ: Lawrence Erlbaum Associates.

19: Greenberg, B. (1988). Some uncommon television images and the drench hypothesis. In S. Oskamp (Ed.), Applied Social Psychology Annual (Vol. 8) Television as a social issue. Newbury Park, CA: Sage.

20: Greenberg. 1. (1987a). A taxonomy of organizational justice theories. Academy of Manaeement Review 12 9-22.

21: Greenberg. J.(1987b). Reactions to procedural injustice in payment distributions: Do the Means justify the ends? Journal of Applied P!|ycholoi)' 72 55-61.

22: Greenberg, 1. \& McCarty, C. (1990). Comparable worth: A matter of justice. In G. R.

Ferris \& K. M. Rowland (Eds.), Research in personneland human resource. manaeement (Vol.

8, PI'. 265-301). Greenwich, CT: IAI Press.

23: Grisaffe, Douglas B. and Fernando Jaramillo (2007), "Toward Higher Levels of Ethics: Preliminary Evidence of Positive Outcomes," Journal of Personal Selling \& Sales

Management, 27, 4 (Fall), 355-371.

24: Greenberg, B. (1988). Some uncommon television images and the drench hypothesis.

In S. Oskamp (Ed.), Applied Social Psychology Annual (Vol. 8) Television

as a social issue. Newbury Park, CA: Sage

25: Greenberg, B. \& Brand, B. (1994). Minorities in the mass media: 1970s to 1990s. In 
J. Bryant and D. Zillmann (Eds.), Media Effects: Advances in Theory and Research.

Hillsdale, NJ: Lawrence Erlbaum.

26: Heckscher, C. (1995). White-collar blues. New York: Basic Books.

Howard, J. L., \& Frink, D. D. (1996). The effects of organizational

restructure on employee satisfaction. Group and Organization Management,

$21,278-303$.

27: Huo, Y.J., Smith, H.J., Tyler, T.R. and Lind, E.A. (1996), "Superordinate identification, subgroupidentification, and justice concerns: is separatism the problem; is assimilation theanswer?", Psychological Science, Vol. 7 No. 1, pp. 40-5.

28: Hsieh, Chaoray and Momtahan, Omid and Karbaschi, Arash and Adibi, Ali and Sullivan, Michael E. and Brady, David J., Implementation of spectral diversity filters using spherical beam volume holograms, Conference Proceedings - Lasers and Electro-Optics Society Annual Meeting-LEOS, vol 1 (2004), pp. 192 - 193 [abs].

29: Hancer, M. \& George R.T. (2003). Job satisfaction of restaurant employees: an empirical investigation using the Minnesota satisfaction questionnaire. Journal of Hospitality \& Tourism Research, 27(1): 85-100.

30: Hersey, P. and Blanchard, K. H. (1977). Management of Organizational Behavior 3rd Edition- Utilizing Human Resources. New Jersey/Prentice Hall.

31: Igalens, J., \& Roussel, P. 1999. 'A study of relationships between compensation package, work motivation and job satisfaction', Journal of Organizational

Behaviour, vol. 20, no. 7, pp. 1003-1025.

32: 1. A.H. Maslow (1954) Motivation and Personality. New York: Harper \& Row.

33: J. Bryant and D. Zillmann (Eds.), Media Effects: Advances in Theory and Research.

Hillsdale, NJ: Lawrence Erlbaum.

34: Kumar,R.,2005,Research methodology: a step by step guide for Beginners, Thousand Oak:Sage.

35:Keung-Fai JW (1996). Job satisfaction of Hong Kong secondary school teachers. Educ. J., 24(2): 29-44.

36: Luthans, F. (2002a). Positive organizational behavior: Developing and managing psychological strengths. Academy of Management Executive, 16(1): 57-72.

37: Landy, Robert, Dramatherapy: Concepts and Practices, Charles C.Thomas Publisher, Springfield, Ill., 1986.

38: Lovelock, C.H. (1992), Managing Services: Marketing, 
Operations, and Human Resources, Prentice-Hall, Upper

Saddle River, NJ.

39: Lee, M. and Koh, J. (2001), "Is empowerment really a new concept? " , international journal of human resource management, Vol.12 No 4,pp.684-95.

40: Lambert, P.J., 2001. The Distribution and Redistribution of Income: A Mathematical Analysis (3rdEdition). Manchester University Press, Manchester.

41: Lambert, R., C. Leuz, and R. Verrecchia. 2007. Accounting information, disclosure, and the cost of capital. Journal of Accounting Research 45: 385-420.

42: Lambert EV, Goedecke JH, Bluett K, Heggie K, Claassen A, Rae DE, West S, Dugas J, Dugas L, Meltzeri S, Charlton K, Mohede I. Conjugated linoleic acid versus high-oleic acid sunflower oil: effects on energy metabolism, glucose toler-ance, blood lipids, appetite and body composition in regularly exercising individuals. Br J Nutr. 2007 May;97(5):1001-11.

43: McFarlin, D. B., \& Sweeney, P. D. (1992). Distributive and procedural

justice as predictors of satisfaction with personal and organizational

outcomes. Academy of Management Journal, 35, 626-637.

44: McFarlin, Dean B., and Paul D. Sweeney (1992). "Distributive and Procedural Justice asPredictors of Satisfaction with Personal and Organizational Outcomes."

45: Michailova, S., and Husted K. "Decision Making in Organizations Hostile to Knowledge Sharing”, Journal for East European Management Studies (9:1), 2004, pp.7-19.

46: Michailova, S., and Husted, K. "Knowledge-Sharing Hostility in Russian Firms", California Management Review(45:3), Spring, 2003, pp.59-76.

47: Michailova, S., and Hutchings, K. "National Cultural Influences on Knowledge Sharing: A Comparison of China and Russia", Journal of Management Studies (43:3), May 2006, pp.383-405.

48: Michailova P.,Petrova N.,Bavero S.,Cavicchioli O.,Ramella L.,Sella G 2000.

49: Malhotra, N., and Mukherjee, A. (2004), 'The Relative Influence of Organizational Commitment and Job Satisfaction on Service Quality of Customer-Contact Employees in Banking Call Centres', Journal of Services Marketing, 18, 162-174.

50: Martensen, A., Dahlgaard, S.M.P., Dahlgaard, J.J., \& Grønholdt, L. (2000). Modelling and measuring employee satisfaction and loyalty: A Danish pilot study. Proceedings of the 3th International QMOD Conference: Quality Management and Organizational Development, Aarhus, Denmark, 20-22 August 2000 (pp. 310-324). Aarhus, Denmark: The Aarhus School of Business

51: Mathieu, J. E., \& Zajac, D. M., (1990). A review and meta-analysis of the antecedents, correlates and consequences of organizational commitment. Psychological Bulletin, 108(2), 
171-194.

52: McGregor, D.H. (1990). Theory X and Theory Y. In Pugh, D.S. (Ed.), Organization Theory-Selected readings (pp. 358-374). London: Pinguin Business.

53: McGregor, D. (1960). The Human Side of Enterprise. New York.

54: Martensen, A. and L. Gronholdt. 2001. Using employee satisfaction measurement to improve people management: An adaptation of Kano's quality type. Total Quality Management, 12 (7\&8), 949-9.

55: Nguyen NT, Goldman C, Rosenquist CJ, et al: Laparoscopic versus open gastric bypass: a randomized study of outcomes, quality of life, and costs. Ann Surg 2001;234:279-289.

56: Nguyen, D.; Smith, N. A.; and Ros'e, C. P. 2011. Author age prediction from text using linear regression. In $\mathrm{LaTeCH} 2011$.

57:Nunnally,J.C.(1970).Introduction to psychological measurement.New York.Mc Graw-Hill.

58: Okpara JO (2004). Personal characteristics as predictors of job satisfaction. An exploratory study of IT managers in a developing economy. Inform. Technol. People, 17(3): 327-338.

59: Opkara JO (2002). The Impact Of Salary Differential On Managerial Job Satisfaction. A Study Of The Gender Gap And Its Implications For Management Education And Practice In A Developing Economy. J. Bus. Dev. Nation, 65-92.

60: Porter, L. W., \& Lawler, E. E. (1968). Managerial attitudes and performance. Homewood, IL: Dorsey Press and Richard D. Irwin.

61: Rotter, J.B. (1966). Generalized expectancies for internal versus external control of reinforcement. Psychological Monographs, 80(1, Whole No. 609).

62: Sokoya, S. K. (2000). Personal predictors of job satisfaction for the public sector manager: Implications for

management practice and development in a developing economy. Journal of Business in Developing Nations, 4, article Retrieved August 20, 2009, [Online] Available: http://www.ewp.rpi.edu/jbdn/jbdnv401.html.

62: Siebert S, Döll P, Feick S, Hoogeveen J, Frenken K (2007) Global map of irrigation areas version 4.0.1.

Johann Wolfgang Goethe University, Frankfurt am Main, Germany / Food and Agriculture Organization of the United Nations, Rome,Italy,http:/www.fao.org/nr/water/aquastat/irrigationmap/index10.stm, Accessed Jun 28, 2010.

63: Saks, A.M., \& Ashforth, B.E. (1996, August). A longitudinal investigation of the relationships between job search intensity, applicant perceptions of fit, and work adjustment. Paper presented at the annual meeting of the Academy of Management, Cincinnati. 


\section{Macrothink \\ International Journal of Human Resource Studies \\ ISSN 2162-3058 2014, Vol. 4, No. 2}

64: Smith PC, Kendall LM, Hulin CL (1969). The Measurement of

Satisfaction in Work and Retirement: A Strategy for the Study of

Attitudes. Rand McNally. Oxford.

65: Sokoya SK (2000). Personal Predictors of Job Satisfaction for the Public Sector Manager. Implications for Management Practice and Development in a Developing Economy. J. Business in Developing Nations.

66: Rizwan, M., Shahzad, N., Sheikh, Q., Batool, S., Riaz, M. \& Saddique, S. (2013) Variables that Have an Impact on Employee Satisfaction And Turnover Intention, International Journal of Research in Commerce, Economics and Management, 3(3), 131-138

67: Thomas, K. W., \& Velthouse, B. A. (1990). Cognitive elements of empowerment: An "interpretative" model of intrinsic task motivation. Academy of Management Review, $15,666-681$

68: Togia, A., et. al. 2004. Job satisfaction among Greek academic librarians. Library \& Information Science Research v. 26 no. 3: 373-83.

69: Wilkinson, L. (1990). Grouping children for learning: Implications for kindergarten education. In E. Rothkoph (Ed.), Review of research in education (pp. 203-223). Washington, DC: American Educational Research Association.

70: Wilkinson, S. (1998) Focus Group Methodology: A Review, International Journal of Social Research Methodology Theory and Practice, 1 (3) pp.181-203.

72: Rizwan, M., Jaskani, J. H., Ameen, H., Hussain, S., Farooq, R. U., and Omair, M. (2013). Antecedents of Employee Satisfaction and it's impact on Job Turnover, International journal of Management Sciences and Business Research, 2(1), 55-64 